Vol. 9 (2000): 177-186.

\title{
Association of antioxidative enzymes with the synergistic effect of selenium and UV irradiation in enhancing plant growth
}

\author{
Tailin Xue \\ Institute of Geography, Chinese Academy of Sciences, Beijing 100101, China \\ Helinä Hartikainen \\ Department of Applied Chemistry and Microbiology, PO Box 27, FIN-00014 University of Helsinki, \\ Finland, e-mail: helina.hartikainen@helsinki.fi
}

\begin{abstract}
Selenium (Se) is able to defend human and animal cells against UV(B) stress. Higher plants are generally considered not to require Se but to have a low tolerance to it. However, recently it has been demonstrated that Se is able to protect also plants against UV-induced oxidative stress and even to promote the growth of plants subjected to high-energy light. In the present study the effects of Se on antioxidative enzymes possibly associated with this synergistic effect were investigated. Ryegrass and lettuce were grown in soil supplemented with $\mathrm{Se}$ at $0,0.1$ or $1.0 \mathrm{mg} \mathrm{kg}^{-1}$ under normal light or subjected to UV episodes. Lipid peroxidation and the changes of antioxidative enzymes were measured at two growing stages. The positive synergistic effect of the lower Se dosage and UV was found to be at least partly associated with the antioxidative role of Se through increased glutathione peroxidase (GSH-Px) and catalase (CAT) activity, whereas ascorbate peroxidase (APX) responded negatively to both factors. The contribution of the other enzymes studied seemed to be plant-specific: glutathione $S$-transferase (GST) increased in both ryegrass assays and superoxide dismutase (SOD) in the first lettuce assay. At the higher addition level Se acted as a pro-oxidant and diminished fresh weight yields. UV irradiation alleviated the toxicity coincidently with increase of CAT in ryegrass and SOD in lettuce.
\end{abstract}

Key words: ascorbate peroxidase, catalase, enzymes, glutathione peroxidase, glutathione $S$-transferase, lipid peroxidation, selenium, superoxide dismutase, ultraviolet radiation

\section{Introduction}

The upward trends of $U V(B)$ radiation linked to ozone depletion may be harmful to living organisms (Kerr and McElroy 1993). Selenium is an essential component of the glutathione peroxidase (GSH-Px) family, which has been shown to be able to resist UV radiation damages in human beings (Ruche and Cesarini 1991, Burke et al. 1992a, Leccia et al. 1993), experimental ani- 
Xue, T. \& Hartikainen, H. Antioxidative enzymes with synergistic effect of Se and UV irradiation

mals (Burke et al. 1992b, Pence et al. 1994, Stewart et al. 1996) and even a human dermatotropic poxvirus (Shisler et al. 1998). Agricultural plants are generally considered not to require Se and to have usually a low tolerance to it. Its toxicity mechanisms have been discussed extensively (for references see e.g. Läuchli 1993), but recently Se has been demonstrated to exert beneficial effects on plants. At proper concentrations it may increase their antioxidative capacity (Hartikainen et al. 1997).

Since some of the detrimental effects of UV irradiation in plants are due to the oxidative stress it produces (Takeuchi et al. 1995, Hideg and Vass 1996), Se can be hypothesized to be able to increase the tolerance of plants against UV. In fact, a previous study of Hartikainen and Xue (1999) demonstrated that Se is able to protect plants against UV-induced oxidative stress and even to promote plant growth under highenergy light. The positive interaction between Se and UV light was manifested e.g. as increased concentrations of nucleic acids and soluble proteins. The antioxidative function of Se was associated with the promotion of glutathione peroxidase (GSH-Px) activity. The element analysis proved that the positive interaction was not assisted by other nutrients $(\mathrm{P}, \mathrm{K}$, $\mathrm{Mg}, \mathrm{Ca}, \mathrm{Mn}, \mathrm{Fe}, \mathrm{Zn}, \mathrm{Cu}$ ).

The objective of the present supplementary study was to gain more detailed information about the role of antioxidative enzymes in their possible association with the synergistic growth-promoting effect of Se and UV irradiation. In addition to glutathione peroxidase (GSH-Px), superoxide dismutase (SOD), catalase (CAT), glutathione $S$-tranferase (GST) and ascorbate peroxidase (APX) were chosen as candidate enzymes due to their importance in cell defence systems. They are normally localised in different cell parts and scavenge different oxygen radicals. GSH-Px scavenges $\mathrm{H}_{2} \mathrm{O}_{2}$ and converts the toxic lipid hydroperoxides to less toxic lipid hydroxide. CAT exists in peroxisomes and catalyzes $\mathrm{H}_{2} \mathrm{O}_{2}$ decomposition, while APX exists in chloroplasts and cytosol, but prin- cipally in chloroplasts, and scavenges $\mathrm{H}_{2} \mathrm{O}_{2}$ produced during photosynthesis (Nakano and Asada 1981, Mittler and Zilinskas 1991). The subcellular localization of plant GST is unclear, but in animal cells the substrates of GSH-Px and GST are similar, as both can scavenge organic hydroperoxides (Habig et al. 1974). In plants, SOD is so far the only enzyme found to specifically scavenge $\mathrm{O}_{2}^{-}$, an initiator in a series of radical chain reactions. This activated oxygen radical is produced in various reactions and metabolic processes involving oxygen, e.g. photosynthesis (Elstner 1991) and respiration (Werf et al. 1991). In order to find out possible changes of antioxidative capacity in response to prolonged stress, the oxidative status of the plants and the enzyme activities were determined at two growing stages.

\section{Material and Methods}

\section{Pot Experiment}

Plant material and cultivation methods are described in our previous report (Hartikainen and Xue 1999). Briefly, ryegrass (Lolium perenne var. Prego) and lettuce (Lactuca sativa var. Australischer gelber) were cultivated in pot experiments in a greenhouse at $20-33^{\circ} \mathrm{C}$ with a coarse-textured soil. For both plants two sets of air-dried, sieved (3-5 $\mathrm{mm}$ ) and homogenized soil samples weighing $4 \mathrm{~kg}$ each were treated with $\mathrm{H}_{2} \mathrm{SeO}_{4}$ to create $\mathrm{Se}$ addition levels of $0,0.1$ and $1.0 \mathrm{mg} \mathrm{kg}^{-1}$ soil, respectively. Then $4.5 \mathrm{~g}$ of ground and homogenized NPK fertilizer (1616-16, Se background $0.1 \mathrm{mg} \mathrm{kg}^{-1}$ ) was mixed with a $3.5 \mathrm{~kg}$ portion of soil, and this soil mixture was put into plastic pots (4 1) and covered with the remaining soil. The seeds $(2.5 \mathrm{~g}$ of ryegrass and 15 seeds of lettuce per pot) were sown onto the upper layer of the soil. After sowing, $100 \mathrm{~g}$ of soil without application of Se and NPK was added to cover the seeds. The experiment was performed in quadruplicate. 
Vol. 9 (2000): 177-186.

During the experiment, daylight was supplemented with Osram Vialox Nav-T 400W lamps to provide a photoperiod of 16 hours and a quantum flux density at the top of the pots of 160 $\mu \mathrm{mol} \mathrm{m} \mathrm{m}^{-2}$. Two weeks after sprouting, one pot set was illuminated every second day for one min by Philips TL-40W/12 Ultraviolet-B (Holland) lamps for two weeks and then for three min daily for the following two weeks. The UV intensity at the top of the pots (measured by Lighting Laboratory, Helsinki University of Technology) was $0.177(280-320 \mathrm{~nm})$ and $0.077(321-360 \mathrm{~nm}) \mathrm{mW} \mathrm{cm}{ }^{-2}$. According to calculations based on the radiation spectrum, a small amount of UV(C) light included in the irradiation episodes amounted to about $4 \%$ of the total energy. During the irradiation treatment the control pots without UV treatment were protected by isolating them with black plastic curtains. The experimental plants were irrigated from below with deionized water applied to the plates.

\section{Plant analyses}

After the first 2-week round of UV irradiation, three small subsamples were randomly taken from the shoots in each pot and and used immediatedly for biochemical analysis as the first assay After the second 2-week round of UV treatment, the whole shoot yield in each pot was harvested. The fresh weight (FW) of the yield was measured and three subsamples were then randomly taken for biochemical analysis as the second assay. In statistical analyses of the results, the mean of three subsamples was taken to represent the result of each pot. The fresh weight yields of the subsamples used for the first assay were added to the final yields.

The fresh plant samples were analyzed for enzyme activities as follows: glutathione peroxidase (GSH-Px, EC 1.11.1.9) by a modified method of Flohe and Gunzler (1984), catalase (CAT, EC 1.11.1.6) by the method of Aebi (1983), glutathione $S$-transferase (GST, EC 2.5.1.18) by the method of Habig et al. (1974), and ascorbate peroxidase (APX, EC 1.11.1.7) by the method described by Mittler and Zilinskas (1991). Superoxide dismutase (SOD, EC 1.15.1.1) was analyzed by the method of Giannopolitis and Ries (1977), where the nitroblue-tetrazolium (NBT) reaction mixtures were illuminated for $3 \mathrm{~min}$ with an Osram Vialox Nav-T $400 \mathrm{~W}$ lamp. In addition to the enzyme activities, the fresh plant material was also analyzed for thiobarbituric reactive substances (TBARS) by a modified method of Yagi (1982) in order to monitor lipid peroxidation. The determination of dry weight (DW), Se and nutrient concentrations, and proteins used in the calculations of enzyme activities are given in Hartikainen and Xue (1999).

\section{Results}

As expected, the effect of added Se and UV irradiation on FW yields (Table 1) followed the same patterns reported previously for DW (Hartikainen and Xue 1999). Under normal light conditions, the lower Se addition did not affect plant growth, but the higher one exerted a toxic effect on both plants. Without added Se, UV irradiation did not affect the growth of ryegrass but diminished the lettuce yield. However, in combination with the high-energy light the lower Se dosage significantly increased FW yields, and the toxicity of the higher addition was alleviated to some extent (Table 1). UV did not affect the Se concentration in ryegrass but reduced it significantly in lettuce cultivated without added Se (Table 1).

In both plants cultivated under normal light, TBARS increased upon prolonged cultivation (Table 2), which indicates enhanced lipid peroxidation. In the control plants not supplied with Se, UV raised TBARS in both assays, demonstrating that the short-wavelength light produced an extra oxidative stress. The added Se reduced the lipid peroxidation irrespective of light conditions, except the higher dosage, which ex- 
Xue, T. \& Hartikainen, H. Antioxidative enzymes with synergistic effect of Se and UV irradiation

Table 1. The fresh weight (FW, $\left.\mathrm{g} \mathrm{pot}^{-1}\right)$ and Se concentration $\left(\mathrm{mg} \mathrm{kg}^{-1}\right.$ dry weight) of the yields at various Se dosages without or with UV irradiation. Data are means of four replicates, values followed by a common letter do not differ at $\mathrm{P} \leq 0.05$ with Duncan test. Each plant and irradiation treatment is tested seperately. The effect of UV irradiation at each Se level is tested by the t-test: $*=$ difference significant at $\mathrm{P} \leq 0.05, * *=$ difference significant at $\mathrm{P} \leq 0.01$.

\begin{tabular}{|c|c|c|c|c|c|c|c|}
\hline & \multirow{2}{*}{$\begin{array}{l}\text { Se added } \\
\mathrm{mg} \mathrm{kg}^{-1}\end{array}$} & \multicolumn{3}{|c|}{ FW } & \multicolumn{3}{|c|}{$\mathrm{Se}$} \\
\hline & & -UV & $+\mathrm{UV}$ & $\begin{array}{c}\text { Effect of UV } \\
(\%)\end{array}$ & -UV & $+\mathrm{UV}$ & $\begin{array}{c}\text { Effect of UV } \\
(\%)\end{array}$ \\
\hline \multirow{3}{*}{ Ryegrass } & 0 & $161 \mathrm{a}$ & $163 b$ & 1.4 & $0.046 \mathrm{c}$ & $0.044 c$ & -5.6 \\
\hline & 0.1 & $164 a$ & $176 \mathrm{a}$ & $7.1 *$ & $5.74 b$ & $5.64 b$ & -1.8 \\
\hline & 1.0 & $130 \mathrm{~b}$ & $147 \mathrm{c}$ & $13 * *$ & $71.9 \mathrm{a}$ & $72.0 \mathrm{a}$ & $>0.1$ \\
\hline \multirow[t]{3}{*}{ Lettuce } & 0 & $158 \mathrm{a}$ & $122 b$ & $-22 *$ & $0.054 \mathrm{c}$ & $0.031 \mathrm{c}$ & $-42 * *$ \\
\hline & 0.1 & $155 \mathrm{a}$ & $174 a$ & $12 * *$ & $6.43 \mathrm{~b}$ & $6.02 \mathrm{~b}$ & -6.3 \\
\hline & 1.0 & $10 \mathrm{~b}$ & $21 \mathrm{c}$ & $108 * *$ & $270 \mathrm{a}$ & $256 a$ & -5.0 \\
\hline
\end{tabular}

Table 2. Thiobarbituric acid reactive substances (nmol malondialdehyde $\mathrm{g}^{-1}$ fresh weight) in shoots in two assays at various Se dosages without or with UV irradiation. Data are means of four replicates, values followed by a common letter do not differ at $\mathrm{P} \leq 0.05$ with Duncan test. Each plant and irradiation treatment is tested seperately. The effect of UV irradiation at each Se level is tested by the t-test: $*=$ difference significant at $\mathrm{P} \leq 0.05, * *=$ difference significant at $\mathrm{P} \leq 0.01$.

\begin{tabular}{|c|c|c|c|c|c|c|c|}
\hline & \multirow{2}{*}{$\begin{array}{l}\text { Se added } \\
\quad \mathrm{mg} \mathrm{kg}^{-1}\end{array}$} & \multicolumn{3}{|c|}{ First assay } & \multicolumn{3}{|c|}{ Second assay } \\
\hline & & -UV & $+\mathrm{UV}$ & $\begin{array}{c}\text { Effect of UV } \\
(\%)\end{array}$ & -UV & $+\mathrm{UV}$ & $\begin{array}{c}\text { Effect of UV } \\
(\%)\end{array}$ \\
\hline \multirow{3}{*}{ Ryegrass } & 0 & $21.9 \mathrm{a}$ & $25.6 \mathrm{a}$ & $17 * *$ & $56.4 \mathrm{a}$ & $80.1 \mathrm{a}$ & $42 * *$ \\
\hline & 0.1 & $18.3 \mathrm{~b}$ & $17.3 \mathrm{c}$ & -5.6 & $46.6 \mathrm{~b}$ & $60.8 b$ & $31 * *$ \\
\hline & 1.0 & $19.1 \mathrm{~b}$ & $20.5 b$ & 5.8 & $40.4 \mathrm{c}$ & $47.3 \mathrm{c}$ & $17^{*}$ \\
\hline \multirow[t]{3}{*}{ Lettuce } & 0 & $13.1 \mathrm{a}$ & $15.0 \mathrm{a}$ & $15^{*}$ & $30.1 \mathrm{~b}$ & $33.1 \mathrm{a}$ & $10 *$ \\
\hline & 0.1 & $9.3 \mathrm{~b}$ & $9.5 b$ & 2.2 & $27.6 \mathrm{c}$ & $26.9 \mathrm{~b}$ & -2.5 \\
\hline & 1.0 & $10.8 \mathrm{~b}$ & $10.9 \mathrm{~b}$ & 1.0 & $38.3 \mathrm{a}$ & $34.3 \mathrm{a}$ & $-10^{*}$ \\
\hline
\end{tabular}

erted a pro-oxidative effect on the second lettuce assay under normal light. Actually, in the young seedlings (the first assay) supplied with Se, UV did not have any effect on TBARS. In the second assay, the antioxidative effect of Se was relative more pronounced in the plants subjected to external UV stress. The pro-oxidative effect of the higher Se addition on lettuce disappeared under UV.

When no Se was added, the activity of all enzymes analyzed decreased upon progressive plant growth (Tables 3 and 4). The added Se did not appear to reverse these decreasing trends. The growth-promoting effect of Se as triggered by UV irradiation was associated at least partly with the increased activity of GSH-Px in both assays (Tables 3 and 4). Irrespective of the light conditions, the lower Se addition increased the activity of GSH-Px in both plants, but the higher dosage depressed GSH-Px in the first lettuce assay. In ryegrass, also UV enhanced GSH-Px activity in all treatments. In lettuce, on the contrary, this response was found in the first assay in all Se-supplied plants but in the second assay 
Vol. 9 (2000): 177-186.

Table 3. Activities of antioxidative enzymes ${ }^{1)}$ in two ryegrass assays at various Se levels without or with UV treatment. Data are means of four replicates, values followed by a common letter do not differ at $\mathrm{P} \leq 0.05$ with Duncan test. Each plant and irradiation treatment is tested seperately. The effect of UV irradiation at each Se level is tested by the t-test: * = difference significant at $\mathrm{P} \leq 0.05, * *=$ difference significant at $\mathrm{P} \leq 0.01$.

\begin{tabular}{|c|c|c|c|c|c|c|c|}
\hline & \multirow{2}{*}{$\begin{array}{l}\text { Se added } \\
\mathrm{mg} \mathrm{kg}^{-1}\end{array}$} & \multicolumn{3}{|c|}{ First assay } & \multicolumn{3}{|c|}{ Second assay } \\
\hline & & -UV & $+\mathrm{UV}$ & $\begin{array}{c}\text { Effect of UV } \\
(\%)\end{array}$ & -UV & $+\mathrm{UV}$ & $\begin{array}{c}\text { Effect of UV } \\
(\%)\end{array}$ \\
\hline \multirow[t]{3}{*}{ GSH-Px } & 0 & $10.1 \mathrm{c}$ & $12.8 \mathrm{~b}$ & $26.8 * *$ & $3.98 \mathrm{c}$ & $4.70 \mathrm{~b}$ & $18.2 *$ \\
\hline & 0.1 & $13.3 \mathrm{a}$ & $16.7 \mathrm{a}$ & $25.5 * *$ & $5.35 \mathrm{a}$ & $6.62 \mathrm{a}$ & $23.7 * *$ \\
\hline & 1 & $11.5 \mathrm{~b}$ & $15.8 \mathrm{a}$ & $37.3 * *$ & $4.93 \mathrm{~b}$ & $5.34 \mathrm{~b}$ & $8.37 *$ \\
\hline \multirow[t]{3}{*}{ CAT } & 0 & $7.39 \mathrm{a}$ & $6.82 \mathrm{a}$ & $-7.7 *$ & $2.89 \mathrm{a}$ & $2.90 \mathrm{~b}$ & 0.6 \\
\hline & 0.1 & 7.34a & $6.87 \mathrm{a}$ & -6.4 & $2.24 \mathrm{~b}$ & $3.26 \mathrm{a}$ & $45.7 *$ \\
\hline & 1 & $8.53 a$ & $6.75 \mathrm{a}$ & $-20.9^{*}$ & $2.44 \mathrm{~b}$ & $3.49 \mathrm{a}$ & $43.4 *$ \\
\hline \multirow[t]{3}{*}{ SOD } & 0 & $0.51 \mathrm{a}$ & $0.41 \mathrm{a}$ & $-19.5^{*}$ & $0.28 \mathrm{a}$ & $0.29 \mathrm{a}$ & 2.0 \\
\hline & 0.1 & $0.38 \mathrm{~b}$ & $0.22 \mathrm{c}$ & $-40.9 * *$ & $0.30 \mathrm{a}$ & $0.28 \mathrm{a}$ & $-8.2 *$ \\
\hline & 1 & $0.37 \mathrm{~b}$ & $0.31 \mathrm{~b}$ & $-18.5^{*}$ & $0.27 \mathrm{a}$ & $0.21 \mathrm{~b}$ & $-24.3^{* *}$ \\
\hline \multirow[t]{3}{*}{ GST } & 0 & $2.66 \mathrm{a}$ & $1.77 \mathrm{a}$ & $-33.2 * *$ & $0.89 \mathrm{~b}$ & $0.83 a$ & -6.1 \\
\hline & 0.1 & $2.00 \mathrm{~b}$ & $2.12 \mathrm{a}$ & 6.1 & $0.66 \mathrm{c}$ & $0.81 \mathrm{a}$ & $22.4 *$ \\
\hline & 1 & $2.79 \mathrm{a}$ & $1.99 \mathrm{a}$ & $-28.6 *$ & $1.20 \mathrm{a}$ & $0.93 \mathrm{a}$ & $-23.0^{*}$ \\
\hline \multirow[t]{3}{*}{ APX } & 0 & $4.25 \mathrm{a}$ & $4.22 \mathrm{a}$ & -0.9 & $1.18 \mathrm{a}$ & $0.97 \mathrm{a}$ & $-18.0 *$ \\
\hline & 0.1 & $4.11 \mathrm{a}$ & $3.60 \mathrm{~b}$ & -12.5 & $1.09 \mathrm{a}$ & $0.96 \mathrm{a}$ & $-11.9 *$ \\
\hline & 1 & $3.85 \mathrm{a}$ & $3.21 \mathrm{~b}$ & $-16.6^{*}$ & $1.03 \mathrm{~b}$ & $0.83 b$ & $-19.7 *$ \\
\hline
\end{tabular}

${ }^{1)}$ Glutathione peroxidase (GHS-Px, nmol GSH mg ${ }^{-1}$ protein $\min ^{-1}$ ), catalase (CAT, mmol $\mathrm{H}_{2} \mathrm{O}_{2} \mathrm{mg}^{-1}$ protein $\min ^{-1}$ ), superoxide dismutase (SOD, unit $\mathrm{mg}^{-1}$ protein $\mathrm{min}^{-1}$ ), glutathione $S$-transferase (GST, $\mu$ mol GS-CDNB mg ${ }^{-1}$ protein $\mathrm{min}^{-1}$ ) and ascorbic peroxidase (APX, $\mu$ mol ascobate $\mathrm{mg}^{-1}$ protein $\mathrm{min}^{-1}$ ).

only at the lower Se level.

The activities of CAT, SOD, GST and APX were not affected or even diminished by the UV irradiation when no Se was added (Tables 3 and 4). Under normal light conditions, in most cases Se addition did not promote the activity of these enzymes, except for the higher dosage, which increased GST in both ryegrass assays (Table 3 ) and CAT in the second lettuce assay (Table 4). In combination with UV in ryegrass, both Se additions promoted CAT in the second assay and the lower dosage GST in both assays. In lettuce, in turn, UV treatment enhanced in the first assay the activity of SOD at both Se levels, and in the second assay CAT at the lower Se level.

\section{Discussion}

The present study was carried out under low background light conditions and some UV(C) light was present, which explains that the impacts of UV irradiation were significant despite short episodes. Nevertheless, the results obtained in both assays agree with those obtained by Takeuchi et al. (1995) with UV(B) showing that the high-energy light enhances the accumulation of lipid peroxidation products. In their study, this reaction pattern was reversed by application of exogenous scavengers of free radicals, such as hydroquinone. In the present study, 
Xue, T. \& Hartikainen, H. Antioxidative enzymes with synergistic effect of Se and UV irradiation

Table 4. Activities of antioxidative enzymes ${ }^{1)}$ in two lettuce assays at various Se levels without or with UV treatment. Data are means of four replicates, values followed by a common letter do not differ at $\mathrm{P} \leq 0.05$ with Duncan test. Each plant and irradiation treatment is tested seperately. The effect of UV irradiation at each Se level is tested by the t-test: $*=$ difference significant at $\mathrm{P} \leq 0.05, * *=$ difference significant at $\mathrm{P} \leq 0.01$.

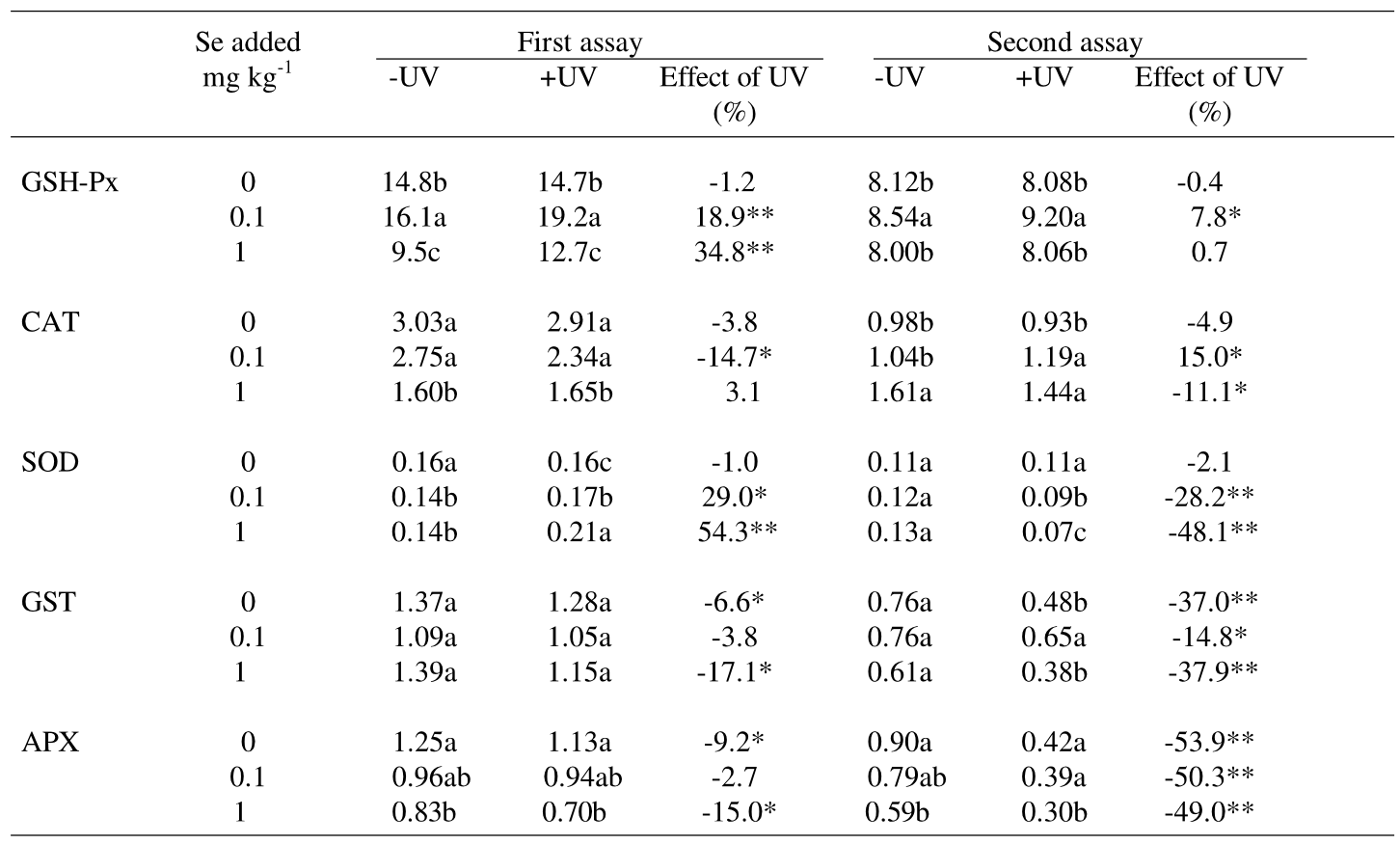

${ }^{1)}$ Glutathione peroxidase (GHS-Px, nmol GSH mg ${ }^{-1}$ protein $\min ^{-1}$ ), catalase (CAT, $\mathrm{mmol}_{2} \mathrm{O}_{2} \mathrm{mg}^{-1}$ protein $\min ^{-1}$ ), superoxide dismutase (SOD, unit $\mathrm{mg}^{-1}$ protein $\mathrm{min}^{-1}$ ), glutathione $S$-transferase (GST, $\mu$ mol GS-CDNB mg ${ }^{-1}$ protein $\mathrm{min}^{-1}$ ) and ascorbic peroxidase (APX, $\mu \mathrm{mol}$ ascorbate $\mathrm{mg}^{-1}$ protein $\mathrm{min}^{-1}$ ).

the added Se took this role and diminished the $\mathrm{UV}$-induced increase in TBARS. However, it reduced the lipid peroxidation irrespective of light conditions, even though in the second assay the antioxidative effect was relatively more pronounced in the plants subjected to the shortwavelenght light.

Jansen et al. (1996) have reported that plants can defend themselves against UV irradiation damage by strengthening their antioxidative systems. The present study suggests that various antioxidative enzymes can be plant-specific and their responses to external stress can vary at different growing stages (Tables 3 and 4). In ryegrass which showed a higher tolerance to UV, the activity of all enzymes, except that of GSHPx was higher than in lettuce.

Willekens et al. (1994) found that ozone, $\mathrm{SO}_{2}$ and $\mathrm{UV}(\mathrm{B})$ had similar effects on mRNA accumulation of antioxidant genes in Nicotiana plumbaginifolia $\mathrm{L}$. The effects of the different stresses were characterized by a decline in CAT1, a moderate increase in CAT3, and a strong increase in CAT2 and GSH-Px, whereas SODs and cyt APX were not affected. However, in the present study the only enzyme increasing in response to UV without Se application in ryegrass was GSH-Px, the scavenger of lipid hydroperoxides and $\mathrm{H}_{2} \mathrm{O}_{2}$. In lettuce where UV diminished the $\mathrm{Se}$ concentration and reduced 
Vol. 9 (2000): 177-186.

plant growth, all antioxidative enzymes responded indifferently or negatively to UV. The antioxidative role of Se was confirmed by the observation that irrespective of light conditions it enhanced GSH-Px activity in ryegrass and strengthened the antioxidative capacity of lettuce when added at non-toxic levels.

The indifferent or negative responses of APX, CAT, GST and SOD to added Se under normal light conditions in the first assay indicate that the antioxidative role of Se diminishing TBARS was not mediated through these enzymes (Tables 2, 3 and 4). Nevertheless, the added Se may have diminished their demand. As result of increased Se concentration GSH-Px activity was enhanced, and this made it possible to scavenge more lipid hydroperoxide and $\mathrm{H}_{2} \mathrm{O}_{2}$. Consequently, the need for enzymes using these radicals as substrate (APX, CAT, GST) may have diminished. Takeda et al. (1997) reported for Chlamydomonas cells that without Seenrichment $40 \%$ of external $\mathrm{H}_{2} \mathrm{O}_{2}$ was scavenged by APX and the residual $\mathrm{H}_{2} \mathrm{O}_{2}$ by CAT, while in Se-containing medium GSH-Px functioned primarily in the removal of external $\mathrm{H}_{2} \mathrm{O}_{2}$. Similar processes may also exist in higher plants. On the other hand, Se might indirectly decrease SOD that catalyses the dismutation of superoxide radicals $\left(\mathrm{O}_{2}^{-} \cdot\right)$ to $\mathrm{H}_{2} \mathrm{O}_{2}$. Superoxide radicals can be used in spontaneous disproportion reactions producing $\mathrm{H}_{2} \mathrm{O}_{2}$ and singlet oxygen (Thompson et al. 1987). Thus, it can be hypothesized that at the same time that Se promotes the scavenging of produced $\mathrm{H}_{2} \mathrm{O}_{2}$ through increased GSH-Px, it also enhances the spontaneous disproportion of superoxide radicals and thus reduces the need for SOD, their scavenger.

Drotar et al. (1985) have hypothesized that GSH-Px scavenges hydrogen peroxide in cytoplasmic compartment. There is, however, no agreement about the occurrence of Se-dependent GSH-Px in higher plants. On the other hand, it has been shown for animal cells, where GSH-Px and CAT are localized in different compartments, that $\mathrm{H}_{2} \mathrm{O}_{2}$ produced, e.g. by mitochondria can diffuse into cytosol, where part of it can be scavenged by GSH-Px. The rest can penetrate further into peroxisomes and be decomposed by CAT (Lawrence and Burk 1978, Fang and Li 1989). When Se is applied, GSH-Px increases and more $\mathrm{H}_{2} \mathrm{O}_{2}$ can be scavenged in the cytosol. Thus the quantity of $\mathrm{H}_{2} \mathrm{O}_{2}$ penetrating into the peroxisomes is reduced and, accordingly, the demand for CAT is relatively decreased. Since GSH-Px and CAT do not compete for $\mathrm{H}_{2} \mathrm{O}_{2}$ in the same compartment and $\mathrm{H}_{2} \mathrm{O}_{2}$ scavenged by GSH-Px is only a fraction of the $\mathrm{H}_{2} \mathrm{O}_{2}$ scavenged by CAT, an increase in GSH-Px activity cannot completely replace the function of CAT.

Although UV irradiation generally diminished the activities of enzymes other than GSHPx irrespective of Se addition, in combination with Se it increased CAT in the second assays of both plants, SOD in the first lettuce assay and GST in the second ryegrass assay. This suggests that Se may increase the antioxidative capacity of plants by multiple systems that act alone or synergistically and are likely different at different growing stages. For instance, in the second assay the antioxidative capacity of ryegrass against UV was strengthened by simultanoeus increase in CAT, GST and GSH-Px.

On the other hand, depressed GSH-Px activity due to Se toxicity in the first lettuce assay coincided under UV with enhanced SOD activity. Although GSH-Px and SOD do not share common substrates and GSH-Px cannot scavenge superoxide anion radicals $\left(\mathrm{O}_{2}{ }^{-} \cdot\right)$ directly, the enhancing influence of Se addition on SOD might be caused by increased demand for antioxidative capacity to counteract Se toxicity. It is possible that the spontaneous disproportion of superoxide radicals producing $\mathrm{H}_{2} \mathrm{O}_{2}$ and singlet oxygen (Thompson et al. 1987) was retarded when the scavenger of $\mathrm{H}_{2} \mathrm{O}_{2}$, GSH-Px, was diminished. Therefore, more SOD activity was needed to detoxify superoxide radicals and to prevent their accumulation.

Similarly, GST and CAT were enhanced as response to increased demand of antioxidative capacity to counteract Se toxicity. It is noteworthy that APX did not increase in order to resist 
Xue, T. \& Hartikainen, H. Antioxidative enzymes with synergistic effect of Se and UV irradiation

UV-induced oxidative stress and always responded negatively to added $\mathrm{Se}$, although it shares a common substrate $\mathrm{H}_{2} \mathrm{O}_{2}$ with GSH-Px and CAT. Analysis of SOD and APX expression carried out by Willekens et al. (1994) in ozonesensitive Nicotiana tabacum L. cv PBD6 revealed that the induction of cytosolic copper/zinc SOD and cyt APX under ozone stress occurs only with the onset of visible damage. In the present study, the Se toxicity resulted in visible symptoms, whereas those caused by UV remained less distinct.

The results show that the synergistic effect of UV and Se added at non-toxic levels on plant growth is at least partly associated with the antioxidative role of Se through increased activity of GSH-Px. The contribution of CAT and GST to the synergistic growth-promoting effect can be concluded from their analogous behaviour; under normal light they responded indifferently or even negatively to Se but increased under UV light. In addition, the slight toxicity-alleviating effect of UV at the high Se addition level seemed to be associated with antioxidative enzymes: the high-energy light increased CAT in ryegrass and SOD in lettuce.

Acknowledgements. We express our thanks to Ms. Marjatta Koivisto for skillfull technical assistance and to the Academy of Finland and Kemira Ltd for financial support.

\section{References}

Aebi, H. 1983. Spectrophotometrical assay of catalase. In: Bergmeyer, H. (ed.). Methods of Enzymatic Analysis. Vol 3. Weinheim: Verlag Chemie. p. 273.

Burke, K. E., Burford, R. G., Combs, G. F. Jr., French, I. W. \& Skeffington, D. R. 1992a. The effect of topical L-selenomethionine on minimal erythema dose of ultraviolet irradiation in humans. Photodermatology, Photoimmunology and Photomedicine 9: 52-57.

- , Combs, G. F. Jr., Gross, E. G., Bhuyan, K. C. \& Abu-Libdeh, H. 1992b. The effects of topical and oral L-selenomethionine on pigmentation and skin cancer induced by ultraviolet irradiation. Nutrition and Cancer 17: 123-127.

Drotar A., Phelps P. \& Fall R. 1985. Evidence for glutathione peroxidase activities in cultured plant cells. Plant Science 42: 35-40.

Elstner, E. 1991. Mechanisms of oxygen activation in different compartments of plant cells. In: Pell, E. \& Steffen, K. L. (ed). Active oxygen/oxidative stress and plant metabolism. American Society of Plant Physiologists Series Volume 6. p. 13-25.

Fang, Y. Z. \& Li, W. J. 1989. Free radicals and enzymes: Basic theories and their application in biology and medicine. Beijing: Science Press. p. 145-146.

Flohe, L. \& Gunzler, W.A. 1984. Assays of glutathione peroxidase. In: Packer $L$ (ed). Methods in Enzymology 105: 114-121. New York: Academic Press.

Giannopolitis, C. N. \& Ries, S. K. 1977. Superoxide dismutases: I Occurrence in higher plants. Plant Physiology 59: 309-314.

Habig, W. H., Pabst, M. J. \& Jakoby, W. B. 1974. Glu- tathione S-transferases: The first enzymatic step in mercapturic acid formation. The Journal of Biological Chemistry 249: 7130-7139.

Hartikainen, H., Ekholm, P., Piironen, V., Xue, T., Koivu, T. \& Yli-Halla, M. 1997. Quality of ryegrass and lettuce yields as affected by selenium fertilization. $\mathrm{Ag}$ ricultural and Food Science in Finland 6: 381-387.

- \& Xue, T. 1999. The promotive effect of selenium on plant growth as triggered by ultraviolet irradiation. Journal of Environmental Quality 28: 1372-1375.

Hideg, E. \& Vass, I. 1996. UV-B induced free radical production in plant leaves and isolated thylakoid membranes. Plant Science 115: 251-260.

Jansen, M. A. K., Babu, T. S., Heller, D., Gaba, V., Mattoo, A. K. \& Edelman, M. 1996. Ultraviolet-B effects on Spirodela oligorrhiza: Induction of different protection mechanisms, Plant Science 115: 217-223.

Kerr, J. B. \& McElroy, C. T. 1993. Evidence for large upward trends of ultraviolet- $B$ radiation linked to ozone depletion. Science 262: 1032-1034.

Lawrence, R. A. \& Burk, R. F. 1978. Species, tissue and subcellular distribution of non Se-dependent glutathione peroxidase activity. Journal of Nutrition 108: 211-215.

Läuchli, A. 1993. Selenium in plants: Uptake, functions, and environmental toxicity. Botanica Acta 106: 455-468.

Leccia, M. T., Richard, M. J., Beani, J. C., Faure, H., Monjo, A. M., Cadet, J., Amblard, P. \& Favier, A. 1993. Protective effect of selenium and zinc on UV-A damage in human skin fibroblasts. Photo- 
Vol. 9 (2000): 177-186.

chemistry and Photobiology 58: 548-553.

Mittler, R. \& Zilinskas, B. A. 1991. Purification and characterization of pea cytosolic Ascorbate peroxidase. Plant Physiology 97: 962-968.

Nakano, Y. \& Asada, K. 1981. Hydrogen peroxide is scavenged by ascorbate-specific peroxidase in spinach chloroplast. Plant \& Cell Physiology 22: 867-880.

Pence, B. C., Delver, E. \& Dunn, D. M. 1994. Effects of dietary selenium on UVB-induced skin carcinogenesis and epidermal antioxidant status. Journal of Investigative Dermatology 102: 759-761.

Ruche, G. la \& Cesarini, J. P. 1991. Protective effect of oral selenium plus copper associated with vitamin complex on sunburn cell formation in human skin. Photodermatology, Photoimmunology and Photomedicine 8: 232-235.

Shisler, J. L., Senkevich, T. G., Berry, M. J. \& Moss, B. 1998. Ultraviolet-induced cell death blocked by a selenoprotein from a human dermatotropic poxvirus. Science 279: 102-105.

Stewart, M. S., Cameron, G. S. \& Pence, B. C. 1996. Antioxidant nutrients protect against UVB-induced oxidative damage to DNA of mouse keratinocytes in culture. Journal of Investigative Dermatology 106: 1086-1089.

Takeda, T., Ishikawa, T. \& Shigeoka, S. 1997. Metabolism of hydrogen peroxide by the scavenging system in Chlamydomonas reinhardtii. Physiologia Plantarum 99: 49-55.

Takeuchi, Y., Fukumoto, R., Kasahara, H., Sakaki, T. \& Kitao, M. 1995. Peroxidation of lipids and growth inhibition induced by UV-B irradiation. Plant Cell Reports 14: 566-570.

Thompson, J. E., Legge, R. L. \& Barber, R. F. 1987. The role of free radicals in senescence and wounding. New Phytologist 105: 317-344.

Werf, A., Van der Raaimakers, D., Poot, P. \& Lambers, H. 1991. Evidence for a significant contribution by peroxidase-mediated $\mathrm{O}_{2}$ uptake to root respiration of Brachypodium pinnatum. Planta 183: 347-352.

Willekens, H., Van Camp, W., Van Montagu, M., Inze, D., Langbartels, C. \& Sandermann, H. J. 1994. Ozone, sulfur dioxide, and ultraviolet $B$ have similar effects on mRNA accumulation of antioxidant genes in Nicotiana plumbaginigolia L. Plant Physiology 106: 1007-1014.

Yagi, K. 1982. Lipid peroxides in biology and medicine. New York: Academic Press. p. 223-230.

\title{
SELOSTUS
}

\section{Seleenin ja UV-säteilyn synergistinen kasvua edistävä vaikutus ja siihen liittyvät antioksidatiiviset entsyymit kasveissa}

\author{
Tailin Xue ja Helinä Hartikainen \\ Kiinan tiedeakatemia ja Helsingin yliopisto
}

Seleeni (Se) on ihmisille ja eläimille välttämätön alkuaine, jonka tiedetään $\mathrm{mm}$. puolustavan soluja UV(B)-säteilyn aiheuttamia vaurioita vastaan. Vallitsevan käsityksen mukaan korkeammat kasvit eivät tarvitse Se:ä, vaan pikemminkin ovat sille varsin arkoja. Äskettäin on kuitenkin osoitettu, että sopivan alhaisina pitoisuuksina Se pystyy suojaamaan myös kasveja UV-säteilyn aiheuttamalta hapetusstressiltä ja jopa edistämään säteilyä saaneiden kasvien kasvua.

Tässä tutkimuksessa selvitettiin Se:n vaikutuksia antioksidatiivisiin entsyymeihin, jotka mahdollisesti liittyvät havaittuun synergismiin. Kasvihuoneesssa toteutetussa kokeessa kasvatettiin raiheinää ja salaattia maassa, johon oli lisätty Se:ä $0,1 \mathrm{mg}$ tai $1,0 \mathrm{mg}$
$\mathrm{kg}^{-1}\left(\mathrm{H}_{2} \mathrm{SeO}_{4}:\right.$ nä$)$ tai jätetty ilman Se-lisäystä. Puolet koekasveista kasvoi normaaleissa valaistusolosuhteissa, puolet altistettiin 1-3 minuutin episodeina annetulle UV-säteilylle. Kaksi ja neljä viikkoa kasvaneista kasveista mitattiin lipidien hapettumista määrittämällä tiobarbituurihapporeaktiivisten aineiden pitoisuudet (TBARS). Lisäksi niistä määritettiin glutationiperoksidaasin (GSH-Px), superoksididismutaasin (SOD), katalaasin (CAT), glutationi- $S$-transferaasin (GST) ja askorbaattireduktaasin (APX) aktiivisuudet.

Ilman Se-lisäystä UV-säteilytys pienensi salaattisatoa (22\%), mutta ei vaikuttanut raiheinän kasvuun. Pienempi Se-lisäys toimi antioksidatiivisesti ja vähensi kummassakin kasvissa valaistusolosuhteista 


\section{AGRICULTURAL AND FOOD SCIENCE IN FINLAND}

Tuorila, H. Consumer perceptions and acceptance of nutritionally modified foods

riippumatta lipidien hapettumista (TBARS pieneni). Yhdessä UV:n kanssa Se-lisäys edisti molempien kasvien kasvua. Ainakin osittain tämä positiivinen synergistinen vaikutus liittyi lisääntyneeseen GSH$P x: n$ ja CAT:n aktiivisuuteen, mutta APX reagoi negatiivisesti sekä Se-lisäykseen että UV-säteilyyn. Muiden tutkittujen entsyymien yhteys havaittuun synergismiin näytti olevan kasvilajikohtaista: raihei- nässä se liittyi GST:n aktiivisuuden lisääntymiseen kummassakin kasvuvaiheessa, sen sijaan nuoressa salaatissa nousi SOD. Suurempi Se-lisäys oli toksinen ja pienensi kuiva-ainesatoja. Mielenkiintoista oli kuitenkin havaita, että UV-säteilylle altistuneissa kasveissa toksisuus lieveni samalla kun CAT nousi raiheinässä ja SOD salaatissa. 